\title{
Curriculum Design for Coaching and Training Center of Archery in the UNIMED
}

\author{
Budi Valianto ${ }^{1}$ Ibrahim $^{2}$ and Indah Verawati ${ }^{3}$ \\ $\left\{\right.$ valiantobudi@gmail.com ${ }^{1}$ \} \\ Sports Coaching Education Program State University of Medan, Indonesia ${ }^{123}$
}

\begin{abstract}
Unimed is a place for sports lovers; many people do sports activities in the Unimed environments. Archery is one sport that is much loved by the people; a sport that needs this concentration becomes a choice of people in the Unimed environment. Although this sport is not too easy to play, certainly there are many ways that can be done, especially making "Archery Curriculum". Sports coaching cannot be separated from how the coaching is done, so that the goal can be achieved optimally. A reflection of how coaching can be done with a good curriculum, certainly it will produce a good generation. Training center of archery is a place to develop them so that they grow thoroughly. This curriculum design was designed to accommodate people's desire to become athletes, extracurricular for school-age children up to college, coach / teacher and match management in archery sports. In the curriculum, it has been determined how the rules are at the beginner level, advanced level, and expert level. The curriculum sets up how the conditions of the rising levels. This is a curriculum design for coaching and training center of archery in the Unimed environment.
\end{abstract}

Keywords: Curriculum, Coaching Center, Archery Training.

\section{Introduction}

The definition of curriculum, which is developed and adhered to by educational experts, is diverse and not just one type. In general, there are two streams that define the curriculum, namely:

a. The curriculum is seen as micro. This view represents those who think that what is meant by the curriculum is the material of a subject that must be conveyed to students. They look at the micro curriculum. Examples of curriculum definitions that belong to this group are: The curriculum comes from the Greek word "curere" which means a place of competition, direction of travel, or a teaching in college (Brotosuroyo, Sunardi \& Furqon, 1992: The curriculum comes from the Latin "curriculum" which means a running course, or race course, especially a chariot race course. The curriculum also comes from the French "courier" meaning "to run" or run. The curriculum is then interpreted as subjects that must be taken to achieve a degree or diploma (Nasution, 1993: 9)

b. The curriculum is viewed in a macro or something that has a wide scope. The curriculum is defined as the entire experience set in school life, from subjects in the classroom to extracurricular activities. Some examples of definitions that represent groups are: Gallen \& Alexander (in Soetopo \& Soemanto, 1993: 13) states that the curriculum is sum is the 
total of school effort to influence learning whether in the classroom, playground or out of school.

Suharsimi Arikunto (1994: 1) states that the curriculum is the entire learning experience developed and prepared for students to cope with life situations with the guidance of educators. The curriculum is a set of plans and arrangements regarding the purpose, content, and learning materials as well as the methods used as guidelines for implementation learning activities to achieve certain educational goals (Article 1 Item 19 of Law No. 20 of 2003 concerning the National Education System). Paying attention to the above definition of curriculum, what is meant by the curriculum is the experiences and activities planned by the school with the aim of modifying student behavior towards expected behavior.

Archery is a sport that uses bows and arrows, in this game each player must be able to shoot bows and arrows about the target that has been determined (Husni, Hakim and Gayo, 1990: 294)

From the definition above can be concluded in this study what is meant by archery curriculum is the experiences and activities designed by the Unimed Archery Coaching and Training Center with the aim of being able to produce reliable athletes, produce Trainers, Referees, and Archery Competition Administrators. from the exercises and programs that are applied to participants and develop archery sports.

In addition to producing athletes who are reliable, Unimed archery training and training centers also provide extracurricular activities for Unimed students, non-Unimed students, kindergarten, elementary, junior high, high school, general, and Sharia.

\section{Curriculum compenents}

According to Soetopo \& Soemanto (1993: 26-36) if the curriculum is seen as a system, the components that become subsystems are (1) goals, (2) material, (3) organization \& strategy, (4) means, and (5) evaluation. The component component of the curriculum is a whole and is reciprocally related. The details of each component are explained as follows:.

\subsection{Objective components}

The object is the direction or target to be addressed by the education process. Therefore, each curriculum has a guideline target that will be achieved or addressed at the end of its implementation. The objective is a guide to evaluating work that has been completed.

The objectives of the Unimed Archery Training and Training Center curriculum are as follows:

(a) To produce reliable athletes who can compete at national and international levels

(b) Produce Trainers, Referees, Archery Race Administrators.

Become a place for students, students, and the general public who want to know and practice archery.

\subsection{Material components}

The next component that is part of the curriculum is material that consists of the content and structure of the program. 
(a) Contents are materials / activities that must be given to participants within a certain period and at a certain level. Material content consists of:

1) Principal material contains program details submitted to participants so that the stated object can be achieved.

2) Teaching or training materials are sequences of subject matter delivery, from the first year to the following year. The sequences are usually based on the character of the material, the ability / interest of the participants.

3) Source of material is the resources used as a source of a number of learning experiences needed by participants. Sources of learning materials can come from people, places and printed and electronic items.

4) Annual Exercise Program.

(b) Program Structure

Based on the training level, curriculum material has the following structure.

1) Achievement Athlete Program

2) Program for Trainers, Referees, Archery Race Administrators

3) Unimed Student Extracurricular

4) Extracurricular Non-Unimed Students

5) Extracurricular kindergarten, elementary, middle school, high school

6) General

7) Sharia.

\subsection{Components of organization and strategy}

In general, experts say that in accordance with existing studies in a field, the curriculum must be organized based on the logical development of the material delivered. Each participant's learning experience must be developed based on the experience that has been completed by the participants, and must develop the skills needed for the next learning experience.

According to Soemanto and Soetopo (1993: 35) the vertical structure of a curriculum shows the preparation of a curriculum based on (1) a class system, the increase in class is held every year simultaneously, (2) a classless program, transfer to another program level every time without pay attention to others, (3) a combination of (1) and (2).

Strategy is a plan that will be used to run a job. The curriculum strategy included is a variety of activities starting with planning to evaluating the curriculum. Thus the curriculum strategy includes: (1) The design of the exercise or learning to be carried out, (2) The method of training or learning that will be implemented and carried out throughout the process, (3) the organization of the training group to be implemented, (4) the form of communication that will done, and (5) how to evaluate the set to find out how much the success level of a training process is.

\subsection{Facility components}

According to Soemanto and Soetopo (1993: 37) the components of the facilities in the curriculum consist of: (a) personal facilities consisting of: teachers, educators who are not teaching, such as counselors, administrative staff, and special staff or advisors, (b) material facilities which includes: instructional materials, physical facilities / buildings / fields, and 
operational costs, and (c) leadership facilities that provide support and safeguards, guidance on program implementation.

In this research, the facility components that are in line with those presented by Soemanto and Soetopo are: (a) Personal facilities consisting of trainers, administration, (b) material facilities include: training program, Unimed archery field and UKM center as administrative buildings, and (c ) means of leadership, namely the head of the Unimed archery coaching and training center.

\subsection{Evaluation components}

Evaluation is an important part of the curriculum. The results of the evaluation of the curriculum can be used as improvement material for the next planning period. Evaluation should be done continuously. Based on that, evaluation of the curriculum that is done will involve two important things, namely:

(a) Evaluation of curriculum results or products.

Evaluation of results aims to assess the extent of the success of the curriculum in delivering students to achieve their intended goals.

(b) Evaluation of the curriculum process.

Evaluation of the curriculum process intends to assess whether the curriculum implementation process takes place as stated. Thus, the objectives set will be monitored for their level of achievement. 


\section{References}

[1] Achmad Damiri.: Panahan. FPOK IKIP, Bandung (1990)

[2] Barrett J.A.: Olahraga Panahan: Pedoman, Teknik dan Analisa. Dahara Prize, Semarang (1990)

[3] Hamalik, Oemar.: Dasar-Dasar Pengembangan Kurikulum. PT Remaja Rosda Karya, Bandung (2009)

[4] Soemanto dan Soetopo.: Pembinaan dan pengembangan kurikulum. Bina Aksara, , Jakarta (1993) [5] Wawan, S Suherman.: Pengembangan Kurikulum Pendidikan Jasmani, Olahraga, Dan Kesehatan, Universitas Negeri Yogyakarta, (2009) 